\title{
WHO/ISUP classification, grading and pathological staging of renal cell carcinoma: standards and controversies
}

\author{
Anne Y. Warren ${ }^{1}$ (D) . David Harrison ${ }^{2}$ (])
}

Received: 1 May 2018 / Accepted: 12 August 2018 / Published online: 19 August 2018

(c) The Author(s) 2018

\begin{abstract}
Purpose Pathological parameters assessed on biopsies and resection specimens have a pivotal role in the diagnosis, prognosis and management of patients with renal cell carcinoma (RCC).

Methods A non-systematic literature search was performed, updated to January 2018, to identify key standards and controversies in the pathological classification, grading and staging of RCC.

Results Although most RCCs exhibit characteristic morphology that enables easy categorisation, RCCs show considerable morphological heterogeneity and it is not uncommon for there to be difficulty in assigning a tumour type, especially with rarer tumour subtypes. The differentiation between benign and malignant oncocytic tumours remains a particular challenge. The development of additional immunohistochemical and molecular tests is needed to facilitate tumour typing, because of the prognostic and therapeutic implications, and to enable more reliable identification of poorly differentiated metastatic tumours as being of renal origin. Any new tests need to be applicable to small biopsy samples, to overcome the heterogeneity of renal tumours. There is also a need to facilitate identification of tumour types that have genetic implications, to allow referral and management at specialist centres. Digital pathology has a potential role in such referral practice.

Conclusion Much has been done to standardise pathological assessment of renal cell carcinomas in recent years, but there still remain areas of difficulty in classification and grading of these heterogeneous tumours.
\end{abstract}

Keywords Renal cell carcinoma $\cdot$ Pathology $\cdot$ Grading $\cdot$ Staging $\cdot$ Review

\section{Introduction}

Pathological parameters assessed on biopsies and resection specimens have a pivotal role in the diagnosis, prognosis and management of patients with renal cell carcinoma (RCC). Standardisation of specimen handling and pathological assessment is, therefore, critical to ensuring that the information contained within histopathology reports is accurate and consistent, for both diagnostic and research purposes. Although various local and national guidelines have been utilised in clinical practice for many years, several recent initiatives have done much to improve consistency at an international level, enabling pathologists to provide

Anne Y. Warren

anne.warren@nhs.net

1 Department of Histopathology, Cambridge University Hospitals NHS Foundation Trust, Cambridge CB2 0QQ, UK

2 School of Medicine, University of St Andrews, St Andrews KY16 9TF, UK the high-quality information required. In 2016, the WHO published a fourth edition of its classification of urological tumours, which is the current internationally recommended system for typing of renal tumours [1]. The updated version of this 'Blue book' also provides epidemiological, clinical and pathological information on the wide range of renal tumours that may be encountered in clinical practice.

\section{Methods}

A non-systematic literature search was conducted using Medline. The reference lists of selected manuscripts were checked manually for eligible articles. The most contemporary guidelines and relevant articles are included, updated to January 2018. 


\section{Results}

\section{Best practice guidelines}

In 2012, the European Network of Uropathology (ENUP) published a survey of the practice of handling nephrectomy specimens by pathologists from 15 European countries [2]. This was followed in the same year by an International Society of Urological Pathology (ISUP) consensus conference on renal tumour pathology in Vancouver. Members of the Society were asked to complete a pre-meeting questionnaire on all aspects of their practice of specimen handling and pathological reporting of renal tumours. The results were presented at the conference by a panel of experts and were discussed and voted upon to determine what should be considered best practice. Following this conference, a series of ISUP publications has provided valuable guidance on specimen handling, tumour typing, grading and assessment of prognostic factors [3-8]. Subsequently, ISUP guidance for pathologists on best practice for use of routine immunohistochemistry in the assessment of renal cell tumours has also been published $[9,10]$.

In addition, the International Committee for Cancer Reporting (ICCR) has devised a series of international datasets for pathologists reporting tumour pathology, with the renal tumour datasets published in 2017 [11, 12]. In the UK, the third edition of the Royal College of Pathologists dataset for renal cancer reporting was published in 2017 [13]. Similar protocols are readily available from, for example, the College of American Pathologists (www.cap.org) and the Royal College of Pathologists of Australasia (www.rcpa.edu.au). These datasets contain guidance on which evidence-based 'core' pathological data items should always be included in histopathology reports, to provide the essential information required for patient management. Other items are also recommended for reporting, but are considered 'non-core' optional data at present due to insufficient evidence of their prognostic significance.

\section{Pathological parameters and stage}

The main core items included in renal tumour pathology reports, currently deemed essential for patient management, are discussed below.

\section{Tumour type}

The 2016 WHO classification of renal tumours is based on a combination of morphological, molecular and genetic features [1]. RCCs represent the most common renal tumour in adults and are divided into a number of different histological types. The most common is the clear cell type (70-90\%), followed by papillary (10-15\%) and chromophobe RCCs (3-5\%). Many studies, including large multicentre studies, have shown that tumour type has prognostic significance $[6$, 14-20]. Tumour type also has utility in selection of patients for adjuvant therapy, further underlining the importance of assigning tumours to the correct category on pathological assessment [21]. The major tumour types are discussed below, with their key pathological features, as well as rarer tumours that have differing clinical significance and may cause diagnostic difficulty.

Clear cell $R C C$ has a worse prognosis than papillary or chromophobe RCCs, when matched for stage, and is more likely to present at an advanced stage or with existing metastases [20, 22-24]. In $90 \%$ of cases, these tumours exhibit alterations in the von Hippel-Lindau tumour suppressor (VHL) gene on chromosome 3 [25]. Most tumours are sporadic, but multiple bilateral tumours are seen in von Hippel-Lindau syndrome, a rare autosomal dominant condition also associated with a variety of other tumours that include haemangioblastomas of the retina and central nervous system [26]. Multifocal sporadic tumours are rare and a recent study has shown that apparent multifocality may be due to retrograde venous invasion from a single tumour [27]. Grossly, clear cell RCCs characteristically contain solid yellow areas with variable amounts of cystic change, haemorrhage and necrosis. Although on microscopy they are classically composed of clear cells set within a fine intricate vascular network, they may consist entirely of cells with eosinophilic granular cytoplasm, particularly if high grade. On immunohistochemistry they characteristically co-express pan-cytokeratin and vimentin and are carbonic anhydrase IX (CA-IX) positive, but are usually Cytokeratin 7 (CK7) negative. The multilocular cystic renal neoplasm of low malignant potential was formerly included in the clear cell carcinoma category, but is now known to have indolent behaviour and an excellent prognosis, regardless of size, with no reported metastases $[6,28]$. It is rare $(<1 \%$ of renal tumours), but is readily diagnosed if morphological criteria are strictly adhered to [1]. These cystic tumours characteristically have thin fibrous septae containing low-grade clear cells, but no solid expansile clear cell nodules that are seen in clear cell RCC. They have been shown to have chromosome $3 p$ deletions and VHL gene mutations similar to clear cell RCCs [1]. Correct pathological diagnosis of these tumours is important, as they may be managed conservatively.

Papillary RCCs are grossly solid, with or without cystic change or encapsulation, and are often grey or brown in colour with a soft friable cut surface showing frequent necrosis and haemorrhage. On microscopy, according to the current WHO classification, they are divided into type 1 or type 2 
tumours, determined primarily by their differing cytological features, and mixed patterns occur [1, 6, 29]. An oncocytic variant (composed of cells with abundant eosinophilic/pink cytoplasm) has also been described morphologically, but is included under the general category of papillary RCC in this classification system $[1,18]$.

Type 1 papillary RCCs usually consist of papillary structures lined by cuboidal cells with low-grade nuclei. Collections of foamy macrophages are often present within the papillary fibrovascular cores and calcifications (psammoma bodies) and intracellular haemosiderin are common. They may also show solid growth, with very compact papillary structures. The tumours have a typical profile on immunohistochemistry, including strong CK7 and alpha-methylacyl-CoA racemase (AMACR) expression and at most focal CA-IX expression. At the molecular level, type 1 tumours typically show gains in chromosomes 7 and 17, and Y chromosome loss. Most tumours are sporadic, but there are familial cases in the autosomal dominant hereditary papillary RCC syndrome, where germline MET proto-oncogene mutations on chromosome 7 result in multiple bilateral tumours [30]. Extrarenal manifestations are not a feature of this familial syndrome [30]. Type 1 tumours generally present with a lower grade and stage at diagnosis and have a better outcome than type 2 tumours [31]. Tumours with the histological appearance of a non-encapsulated type 1 tumour and up to $15 \mathrm{~mm}$ in size are classified as papillary adenomas, rather than carcinomas, because they show benign clinical behaviour [1].

Morphologically, type 2 tumours have cells with more abundant eosinophilic cytoplasm that show nuclear pseudostratification and higher grade nuclei. They also show more variable protein expression on immunohistochemistry than type 1 tumours, often including loss of CK7. At the molecular level, these tumours are associated with NRF2-ARE pathway activation and can be divided into several distinct molecular subtypes that are associated with differing patient survival. Papillary RCCs are now known to represent a much more heterogeneous group of tumours than implied by the 2016 WHO classification [32, 33]. A recent study by Saleeb et al. suggests that using a combination of morphological features, immunoprofiles and molecular analysis, papillary RCCs can be divided into four subtypes and that this type of grouping would be a better means of guiding patient management [34].

Papillary RCC is more often multifocal and bilateral than the other common tumour types, as seen in approximately $10 \%$ of cases [6]. Papillary RCCs are also more frequent in acquired cystic kidney disease.

A less common tumour that may show overlapping morphology with type 1 papillary RCCs, particularly in limited biopsy samples, is the mucinous tubular and spindle cell carcinoma (MTSCC) [1]. This is classically composed of elongated tubules and spindle cells, both cytologically low grade, and abundant intercellular mucin. It has a similar immunohistochemical profile to papillary RCCs, adding to the difficulty in distinguishing these tumours in some cases. Ren et al. have, however, demonstrated that MTSCCs show multiple chromosome losses and lack trisomy 7 and 17, enabling separation on molecular studies [35]. These tumours are more common in females and generally exhibit indolent behaviour, but distant metastases have been reported $[1,18]$.

Chromophobe $R C C$ is usually sporadic and generally has a good prognosis. Most of these tumours are confined to the kidney at diagnosis, though they may be large at the time of presentation [36]. They are characteristically tan in colour, similar to the benign renal oncocytoma that is the main differential diagnosis. On microscopy, chromophobe RCCs characteristically consist of large cells with prominent cell membranes, pale cytoplasm and crinkled 'raisinoid' nuclei with perinuclear halos. An eosinophilic variant also occurs, where the cells have an oncocytic cytoplasmic appearance and the nuclear features described are often less apparent. Chromophobe RCCs are characterised by multiple chromosome copy number alterations [37]. Hybrid oncocytic-chromophobe tumours, with a mixed morphology, may occur sporadically or in the Birt-Hogg-Dubé syndrome. The latter shows autosomal dominant inheritance and is associated with FLCN gene mutations on chromosome 17 [6, 18, 26]. There are associated cutaneous lesions, pulmonary cysts and spontaneous pneumothoraces [30]. The hybrid renal tumours are usually small and show indolent behaviour and are amenable to conservative management [38]. A variety of other renal tumour types have also been reported in this syndrome [30].

Collecting duct carcinoma is a rare (1-2\%) and highly aggressive type of RCC arising in the renal medulla. It may be difficult to distinguish histologically from urothelial carcinoma of the renal pelvicalyceal system, due to similar infiltrative high-grade variable morphology and their overlapping immunohistochemistry profiles. Distinction from metastatic tumours may also be problematic, particularly adenocarcinomas, and diagnosis is by exclusion of other entities. Metastatic disease is common at the time of diagnosis and the majority of patients do not survive 2 years from diagnosis $[1,18]$. Renal medullary carcinoma has similar morphology and occurs in association with sickle cell trait or disease. This is rare, aggressive and occurs more often in younger adults. In contrast to collecting duct carcinomas, these tumours may express OCT3/4 on immunohistochemistry and show loss of expression of SMARCB1 (INI1) [1, 39].

MiT family translocation RCCs are rare and should be considered particularly in children and young adults presenting 
with RCC, although they also occur in the adult population [40]. They result from gene fusions involving the MiT transcription factor genes TFE3 and TFEB, with differing fusion partners. The best morphologically described tumours of the group are those associated with Xp11 and $t(6 ; 11)$ translocations. The former may be recognised by their distinctive clear cell morphology with voluminous cells, and a papillary architecture, sometimes with frequent calcifications (psammoma bodies). The less common $t(6 ; 11)$ translocation tumours have a characteristic biphasic pattern with distinct groups of large and small epithelioid cells. The MiT family translocation RCCs commonly show weak expression of epithelial markers on immunohistochemistry and some express melanoma markers and cathepsin-K. Diagnosis requires fluorescence in situ hybridisation (FISH) to confirm the presence of the translocation, as use of immunohistochemistry has proven technically challenging. They may exhibit aggressive clinical behaviour, particularly in adults or those with the Xp11 translocation, and tend to develop early nodal metastases $[1,18,36,41]$. They may be erroneously classified pathologically as clear cell RCCs, particularly when occurring in the adult population. This is of clinical significance, as they may not respond to the vascular endothelial growth factor (VEGF)-targeted treatments.

Newly recognised types A number of provisional tumour types recognised at the 2012 ISUP Vancouver consensus meeting have been included as separate entities in the 2016 WHO classification, as their morphology, immunoprofile and molecular characteristics are now better understood [1, 6]. These include the clear cell papillary RCC that shows indolent behaviour, with no reported local recurrences or metastases, but would have been previously diagnosed as a clear cell RCC [42]. These are usually small tumours and are often cystic with compact tubulo-papillary solid areas. A distinctive morphological feature is the linear orientation of tumour cell nuclei away from the basement membranes, although a similar appearance may be seen focally in clear cell RCCs. On immunohistochemistry they are strongly CK7 positive, unlike most clear cell RCCs, high molecular weight cytokeratin positive, AMACR negative and exhibit a distinct 'cup-shaped' staining pattern with CA-IX. Molecular studies show them to be distinct from clear cell and papillary RCCs [1]. They occur sporadically or in association with acquired cystic renal disease and are now recognised as being the fourth most common type of renal cell carcinoma [42]. Another tumour occurring more frequently in the clinical setting of acquired cystic kidney disease is the acquired cystic kidney disease-associated RCC. These tumours usually show indolent behaviour unless exhibiting high-grade features. They often appear to arise within a cyst and are commonly multifocal and bilateral. Characteristic morphological features are a 'sieve-like' architecture and the presence of abundant oxalate crystals [1]. They are typically AMACR positive, but CK7 and CA-IX negative. They frequently occur with other renal tumour types [43].

Tubulocystic RCC is another rare, usually indolent, good prognosis tumour type more frequently seen in men. It was thought to be related to papillary RCCs, but is now accepted as a separate entity $[1,44]$. It has a characteristic 'bubble wrap' appearance grossly, due to the presence of fibrotic stroma separating cystic spaces. Small tubules are present within the stroma microscopically and are lined by cells with eosinophilic cytoplasm and round nuclei with nucleoli of variable prominence. The tumour cells may also have a "hobnail' appearance $[1,18]$. These tumours express AMACR and CK7 on immunohistochemistry. On molecular analysis, there have been conflicting reports, but in recent series of RCCs with a pure tubulocystic morphology, trisomy of chromosomes 7 and 17 observed in papillary RCCs was not present and these tumours have also been shown to have a molecular signature distinct from the more common RCC tumour types [45-47]. Other tumours may show areas with a tubulocystic pattern, including papillary RCCs, hereditary leiomyomatosis renal cell carcinoma-associated RCC, the MiT family translocation RCCs, collecting duct carcinoma and unclassified RCCs, causing diagnostic difficulty, but such tumours with mixed morphology are not included in this tumour category.

Hereditary tumours Less than 5\% of renal cell carcinomas are associated with hereditary syndromes [30, 48]. In addition to those occurring in the previously described von Hippel-Lindau, hereditary papillary renal cell carcinoma and Birt-Hogg-Dubé syndromes, there are also a number of more recently recognised hereditary renal tumours.

Succinate dehydrogenase-deficient $R C C$ is rare and results from inherited germline mutations in the succinate dehydrogenase (SDH) gene, most commonly SDHB but also in SDHA, SDHC and SDHD. Affected patients may also present with paragangliomas and gastrointestinal stromal tumours (GISTs). The associated RCCs may be multifocal and bilaterality occurs in around $25 \%$ of cases [49]. On microscopy, the RCCs are usually solid and are composed of cells with eosinophilic cytoplasm with distinctive cytoplasmic vacuolation and inclusions, although focal limited presence of these changes may hamper pathological recognition [50]. Intratumoral mast cells are also a common feature. Immunohistochemistry for demonstration SDHB is available, where a loss of staining is indicative of a mutation in the SDHB (most common), SDHC or SDHD genes. SDHA gene mutation can be demonstrated by additional absence of staining for SDHA. Most tumours are low grade and have a good prognosis, but those exhibiting high-grade features, 
sarcomatoid morphology or necrosis may show aggressive behaviour, with a high rate of metastasis up to $70 \%[1,50]$.

Patients with RCC associated with hereditary leiomyomatosis and renal cancer syndrome have an autosomal dominant inherited germline mutation in the $\mathrm{FH}$ gene on chromosome 1 that encodes for fumarate hydratase [26, 30]. This syndrome is also associated with cutaneous and uterine leiomyomata, occurring at greater frequency than the associated RCCs. These tumours are high grade and often have a papillary architecture, with tumour cells having eosinophilic cytoplasm. However, the morphology may be very variable and lead to misdiagnosis, for example, as an unclassified RCC, collecting duct carcinoma or type 2 papillary RCC, particularly as they may be solitary and, therefore, not suspected to be part of a hereditary syndrome [51]. A characteristic histological feature is the presence of distinctive prominent nucleoli with perinucleolar halos, exhibiting an appearance reminiscent of cytomegalovirus inclusions [52]. On immunohistochemistry, the combination of a lack of FH expression and overexpression of $S$-(2-succino)cysteine (2SC) suggests a diagnosis of FH-deficient RCC, which can then be confirmed with molecular studies. These are highly aggressive tumours, even when of small size, and show frequent distant metastases [30, 53]. Cases of FH-deficient RCC that are not obviously associated with the hereditary syndrome have been shown to have a similar presentation and clinical course. It has, therefore, been suggested that germline testing and counselling should also be undertaken in these cases when diagnosed pathologically [54, 55].

The tuberous sclerosis complex is associated with mutations in the TSC1 (on chromosome 9) or TSC2 (on chromosome 16) genes encoding for hamartin or tuberin, respectively, and shows autosomal dominant inheritance with variable penetrance. A variety of associated tumour types typically involve the skin, brain, retina, heart or kidney. The most common tumours in the kidneys are multiple angiomyolipomas, but RCC also occurs rarely and at a younger age than sporadic tumours [56, 57]. The RCCs in this syndrome have been described as exhibiting three differing morphological growth patterns: the most common are RCCs with prominent smooth muscle stroma and voluminous clear cells with a tubulopapillary growth pattern, and the others resemble chromophobe-like RCCs or are similar to the sporadic eosinophilic solid and cystic RCC which is further described below [56]. The tumours show indolent behaviour. Previously undiagnosed tuberous sclerosis complex may be suspected if such tumours are seen in combination with multiple angiomyolipomas.

Other tumour types There are several other tumour types that have been described in recent years, but are not currently recognised as separate entities in the WHO classification. The eosinophilic solid and cystic RCC is a rare tumour predominantly occurring in adult females, with a broad age range $[58,59]$. Paediatric cases have also been described [60]. It occurs sporadically and is identical to a group of tumours occurring in patients with the tuberous sclerosis complex. Morphologically it is characterised by a solid and cystic growth pattern, with constituent cells having voluminous eosinophilic cytoplasm with prominent granular stippling. The tumour is distinct in frequently showing CK20 positivity and typically a lack of expression of CA-IX and CK7. Limited molecular studies have demonstrated recurring copy number alterations and TSC 1 or TSC 2 mutations in the sporadic tumours $[59,61,62]$. The tumours usually show indolent behaviour, but metastatic disease has been reported [60].

A number of other tumours of which there is limited experience at present include thyroid-like follicular RCCs, RCCs with angioleiomyomatous stroma, the oncocytic RCC that occurs post-neuroblastoma treatment and RCCs exhibiting ALK gene rearrangements, monosomy 8 and TCEB 1 mutations [1].

Unclassified RCC Approximately 5\% of tumours remain difficult to categorise after thorough sampling and immunohistochemical assessment, because the tumour is purely sarcomatoid, the immunoprofile is not definitive or there are unusual or overlapping morphological features. Tumours composed of eosinophilic cells have been shown to cause particular difficulty in classification when they do not show distinctive features [63]. Such tumours are placed in the 'unclassified' category. This category will include both low- and high-grade tumours; therefore, pathologists are advised to describe the findings, so that it is clear in pathology reports at which end of the grading spectrum the unclassified tumour lies.

\section{Challenges in tumour typing}

Although most RCCs exhibit characteristic morphology that enables easy categorisation, with or without the assistance of routine immunohistochemistry, it is not uncommon for there to be difficulty in assigning a tumour type. RCCs show considerable morphological heterogeneity, with clear cells, oncocytic cells or a papillary architecture seen in a variety of renal tumours. A particularly problematic area is the separation of oncocytic tumours, where benign and malignant entities may have overlapping morphology. It is well known that distinguishing a benign renal oncocytoma from a chromophobe RCC may be difficult, particularly as fat invasion or vascular involvement, features normally associated with malignancy, does not necessarily exclude the diagnosis of an oncocytoma [64]. CK7 immunohistochemistry may help, as oncocytomas should show only focal staining whereas there is strong and diffuse staining in most chromophobe 
RCCs. Fluorescence in situ hybridisation (FISH) can also be utilised, as multiple chromosome abnormalities typically occur in chromophobe RCCs, but this investigation is not necessarily routinely available. Even expert renal tumour pathologists report problems in this area, with only $64 \%$ of a group of world experts willing to definitively report benign oncocytomas on biopsy samples [65].

Panels of antibodies are used in immunohistochemistry to aid classification of tumours lacking typical morphology. However, routinely available antibodies do not exclusively stain one particular tumour type, thus creating diagnostic difficulty when the immunoprofile is not conclusive. In addition, some antibody stains may be positive adjacent to areas of necrosis, such as CA-IX or CK7, thus there may be aberrant staining in partly necrotic tumours in which these antibodies are usually negative, leading to misinterpretation of results.

Furthermore, high-grade tumours, particularly in a metastatic setting, may lose characteristic morphological features and immunoprofiles, making confirmation of renal origin and tumour subtyping difficult. Pax- 8 is helpful for determining renal origin, but is also positive in tumours from other sites, such as the thyroid gland and gynaecological tract tumours of Müllerian origin. Additionally, the rarity of some tumours, which may show only subtle morphological changes from the more common RCC types, makes it difficult to ensure that pathologists are able to recognise these unusual tumour types. In current practice, those tumours that do not exhibit sufficiently characteristic morphological features or immunoprofiles to allow confident categorisation into one of the known tumour types, therefore, remain 'unclassified'.

\section{Tumour grade}

The Fuhrman grading system, assessing nuclear and nucleolar features, has been in international use for many years [66]. Although it has proven prognostic utility, intra- and inter-observer reproducibility has been problematic, due to difficulties in consistently applying the four grades as described morphologically [67-70]. A new WHO/ISUP grading system has been introduced following the conclusions of the 2012 ISUP Vancouver conference and is recommended for use by the WHO $[1,5]$. This is also a four-grade system, with the degree of nucleolar prominence assessed to determine grades 1-3 and the presence of highly atypical 'pleomorphic' cells and/or sarcomatoid or rhabdoid morphology (see below) defining grade 4 . The tumour grade is assigned according to the highest grade cells present, rather than the most predominant. In practice, the new WHO/ISUP grading, though similar to the Fuhrman system, is easier to apply and should be more reproducible and clinically relevant.
The WHO/ISUP grading system only applies to clear cell and papillary RCCs, as its prognostic utility has not been validated for other tumour types [67-70]. Although different grading systems have been proposed for chromophobe RCC, to date, none have been internationally accepted for use in clinical practice [71, 72]. Collecting duct carcinomas are not graded, as by definition they are aggressive highgrade tumours. Grading of RCCs should be more consistent following the introduction of the WHO/ISUP grading system. However, grading is still subject to variation depending upon the extent of sampling of tumours, which may show only focal high-grade areas, and an individual pathologist's microscopic assessment.

It has been proposed, though not formally accepted, that tumour necrosis should be incorporated into the WHO/ISUP grading system, to further refine the prognostic significance of tumour grades, as some studies have shown that the presence or absence of necrosis influences prognosis within a specific tumour grade [73, 74]. More recently, the prognostic relevance of the different morphological patterns observed in clear cell RCC has lead to the proposal of a different grading system based on tumour architecture [75].

\section{Tumour necrosis}

Tumour necrosis is included in prognostic algorithms for patient management, but only histological coagulative necrosis is recognised to have prognostic significance, as grossly visible tumour necrosis is possibly due to a different mechanism (probable infarction due to the presence of tumour thrombus) [76]. Tumour necrosis has been shown to have prognostic significance for clear cell and chromophobe RCCs, independent of tumour stage and grade [5, 22, 77-79]. Papillary RCCs often contain areas of necrosis and its presence in this tumour type, therefore, lacks the same significance. However, a study of a series of type 1 papillary RCCs by Peckova et al. demonstrated a good clinical outcome for cystic and extensively necrotic tumours [80]. Necrosis has also been shown to be an adverse prognostic factor in $t(6,11)$ translocation RCCs [81]. A study by Collins and Epstein of RCCs with extensive necrosis has, however, shown the situation to be more complex, with widespread cystic necrosis in high-grade tumours associated with a worse prognosis, but suggesting a good prognosis for low-grade tumours where the tumour type, grade and stage have greater prognostic significance [82]. Necrosis may also influence treatment efficacy, as, for example, the response to VEGF/tyrosine kinase inhibitor-targeted therapy has been shown to be poor in patients with metastatic disease where there was $10 \%$ or more necrosis in the primary clear cell RCC [83].

The quantity of tumour necrosis has been reported to affect the prognostic significance, not simply its presence 
[84-86]. However, although it has been recommended that the proportion of necrosis is recorded in histology reports, there is no international agreement as yet on how this can be reliably assessed pathologically [5].

\section{Sarcomatoid and rhabdoid morphology}

High-grade morphological features, such as the presence of cells with a sarcomatoid appearance, are associated with a poor outcome, with 15-22\% 5-year survival reported and distant metastases commonly present at diagnosis (45-77\%) [5, 87-90]. On histology, the most common pattern seen is a spindle cell sarcoma morphology; however, any pattern of sarcoma may be seen, including fibrosarcoma, chondrosarcoma and many others [91]. This appearance may be present in any of the main tumour types, occurring in approximately $5 \%$ of cases [5]. There is no minimum amount of sarcoma that needs to be seen to record this component. Tumours consisting only of sarcomatoid cells are placed in the 'unclassified' category in the WHO classification [1]. The extent of sarcomatoid morphology has been shown to adversely affect survival, but there is no international agreement on how this can be measured and reported reliably $[92,93]$.

Rhabdoid morphology refers to the presence of large atypical cells with eccentric nuclei. Its presence is also reported to be associated with a poor prognosis [94-96]. It may occur in any RCC type, but is most commonly seen in clear cell RCCs [97]. At the molecular level, an association has been shown between the rhabdoid phenotype and alterations in the switch/sucrose nonfermentable (SWI/ $\mathrm{SNF}$ ) chromatin modelling complex, similar to that noted in aggressive carcinomas from other sites exhibiting a rhabdoid or undifferentiated phenotype [98].

Sarcomatoid and rhabdoid cells may occur together and are both classified as WHO/ISUP grade 4 [1]. The presence of sarcomatoid morphology has, however, been shown to have a more significant association with death from RCC than the presence of rhabdoid morphology [99].

\section{Tumour stage}

Pathological tumour stage (TNM) is the most important prognostic factor for RCC and is derived from assessment of macroscopic and microscopic features [14, 100]. These include the tumour size and determination of the presence or absence of invasion into the perinephric fat, the renal sinus or Gerota's fascia, involvement of the renal vein or inferior vena cava, direct invasion of or metastatic spread to the adrenal gland and lymph node metastases.

The 7th editions (TNM7) of the Union for International Cancer Control (UICC) and the American Joint Committee on Cancer (AJCC) TNM staging systems have been in use worldwide for over 7 years and have been validated in clinical practice [101, 102].

Recently, the 8th editions (TNM8) of the alternative UICC and AJCC staging systems were published [103, 104]. Initially, there were a number of differences between the two in a range of tumour sites, including urological tumours, but following publication of errata, the pathological TNM stage is now closely aligned for renal tumours, although significant differences still exist in the prognostic stage groupings $[105,106]$. TNM8 has been recommended for use from 1st January 2018 [103, 104]. Although much of the TNM pathological staging remains unchanged in TNM8, there are a few significant changes from TNM7 which are mentioned in the relevant sections below.

pT1 and pT2 Tumour size is part of TNM staging, with 40, 70 and $100 \mathrm{~mm}$ being the boundary points for increasing stage categories (pT1a, pT1b and pT2a, respectively). The maximum diameter of the tumour (excluding any intravascular extension), is assessed on macroscopic examination. For localised clear cell RCC, tumour size has been shown to correlate with clinical outcome, with increasing tumour size correlating with a worse prognosis [107]. Most tumours that exceed a maximum of $70 \mathrm{~mm}$ diameter show renal sinus involvement (fat or vascular invasion) and are, therefore, of higher stage [108].

$p T 3$ The presence of perinephric fat invasion is part of TNM staging (pT3a). The nature of the invasive edge, whether pushing (rounded) or infiltrative, has been shown to have prognostic significance, with 3-year survival rates of $75 \%$ and $27 \%$, respectively, although specification of the growth pattern is not currently a required item for pathology reports [109].

Renal sinus invasion, defined as invasion into sinus fat/ connective tissue or within vascular spaces, is the principal route of extra-renal spread of RCCs (pT3a). Through the extensive work of Bonsib, it is now recognised as a vital area for pathological assessment to ensure accurate staging [110-112]. The presence of renal sinus invasion has been shown to be associated with more aggressive tumour behaviour than perinephric fat invasion [113].

Only gross invasion of the renal vein or its 'muscle containing segmental branches' is included in TNM7 stage pT3a. However, for TNM8, the requirement for 'gross' invasion is removed, as is the need for involved branches (tributaries) of the renal vein to contain muscle. The TNM8 pT3a stage, therefore, includes the presence of any involvement of the renal vein and its branches, whether identified grossly or microscopically.

Invasion of the pelvicalyceal system has been shown in some studies, including a meta-analysis involving over 9000 patients, to be associated with poor survival and to reduce 
recurrence-free survival [114-117]. It is not part of TNM7 staging, but is included in TNM8 as pT3a.

pT3b is defined as involvement of the inferior vena cava (IVC) below the diaphragm and pT3c as IVC involvement above the diaphragm or if there is evidence of direct invasion of the vein wall at any level. In TNM8, the need for the IVC involvement to be visible grossly has been removed.

$p T 4$ The presence of direct invasion of the ipsilateral adrenal gland has a poor outcome and is TNM stage pT4 [78, 84]. It is present in $2 \%$ of cases at nephrectomy and is more often seen in large tumours, those in the upper pole or those with vascular invasion [118]. Invasion of Gerota's fascia, taken as the surgical margin of the fat at nephrectomy, is also pT4.

$p N$ Palpable lymph nodes are found in the hilar region in less than $10 \%$ of nephrectomy cases [119]. Although survival rates fall progressively as the number of lymph nodes involved by metastatic tumour increases, the TNM staging has only two categories for regional node status: $\mathrm{pN} 1$ for one or more positive nodes and pNO if they are uninvolved.

$p M \mathrm{pM} 1$ is the category assigned for pathologically proven distant metastases. Adrenal metastases are stage pM1, as are nodal metastases beyond the regional lymph nodes or at other distant sites.

\section{Lymphovascular invasion}

Lymphovascular (microvascular) invasion (other than that within the perinephric or renal sinus fat in stage pT3a) is not part of TNM staging. However, it has been reported to correlate with survival, independent of tumour size, grade or type, and to have prognostic significance in low-stage RCC, independent of tumour grade [120-123]. Lymphatic spread to hilar lymph nodes is less often seen in clear cell RCCs than in papillary RCCs or collecting duct carcinomas.

\section{Surgical margins}

All surgical margins are assessed routinely in pathology, with margin involvement by tumour being generally regarded as a risk factor for local tumour recurrence. Patients with residual disease post-nephrectomy have poorer survival [124]. The presence of invasion of the renal vein wall at the surgical margin of the vein is also a risk factor for local recurrence [125]. Assessment of the parenchymal surgical margin is of importance for partial nephrectomy specimens, although one large study of over 3800 cases has shown a lack of correlation between the presence of a positive surgical margin and tumour recurrence [126].

\section{Potential future improvements}

\section{Biomarkers}

There is a need to develop more reliable and readily available biomarkers for immunohistochemistry that have diagnostic, predictive and prognostic utility. Similarly, development of validated molecular tests and pathways for easy access to this advancing technology is necessary. Such tests need to be able to overcome the heterogeneity of renal tumours that affects grading and molecular characteristics in different regions of the tumour. Development of molecular tumour profiles may enable prediction of behaviour of those tumours for which the current WHO/ISUP grading system is not applicable or might obviate the need for microscopic assessment of tumour grade.

Any new tests need to be applicable to small biopsy samples. Biopsies of renal masses or metastases are becoming more frequent, being used to guide management of small renal masses and systemic treatments of metastatic disease. When an adequate sample has been achieved, renal biopsies have been shown to be highly sensitive and specific, with low complication rates [127, 128]. However, such samples, by virtue of the limited amount of tissue available and the heterogeneity of renal tumours, do pose problems with pathological diagnosis, tumour typing and assessment of grade $[129,130]$. There is, therefore, a need to develop validated methods of utilising these small amounts of tumour tissue to obtain information critical for patient management.

\section{Education and improved referral pathways}

Many nephrectomy and biopsy specimens will be reported outside specialist centres. It is, therefore, crucial that pathologists in the wider community are able to recognise less familiar tumour types that potentially influence patient prognosis and management or have genetic implications. In the UK, for example, there is a national uropathology external quality assessment (EQA) scheme (www.histopatho logyeqa.org) which has an educational role in improving standards. Pathologists are expected to participate in EQA schemes relevant to their areas of clinical practice, regularly assessing slides and receiving feedback on their performance in comparison with their peers. This type of activity and the availability of educational courses, guidelines and online resources have significantly improved knowledge of renal tumour pathology. Nonetheless, infrequent tumour types may be misdiagnosed. Referral for expert opinion is always an option, initiated by the reporting pathologist, but it is suggested that for specific cases, such as tumours occurring in younger adults, or where there is a family history or presence of multiple tumours, there should be automatic referral to a specialist centre for pathology review. This is particularly 
important where further FISH or molecular tests are deemed necessary.

\section{Digital pathology}

The advent of rapid whole-slide scanning technology, enabling the production of high-resolution and high-quality 2D and 3D digital images from conventional glass slides, has brought with it considerable opportunities for the future practice of renal tumour pathology, as well as pathology as a whole.

In clinical practice, there are the potential advantages of remote reporting and for obtaining rapid second opinions, without the need for costly and time-consuming transportation of glass slides between laboratories. Work may be distributed digitally, from centres with staff shortages, to pathologists available at geographically distant centres, thus maintaining reporting turnaround times [131]. For rarer renal tumour entities, it is possible for pathologists to share images and to obtain rapid expert opinions from around the world. Case review for multidisciplinary team meetings is facilitated by enabling images to be shared across a number of centres simultaneously. Digital macroscopic and microscopic images of specimens can also be incorporated into pathology reports and stored on hospital patient information systems.

Image analysis techniques have the potential to remove subjectivity and inter-observer variation from, for example, tumour grading, by enabling digital assessment of nucleolar size and nuclear features. The development of computerassisted diagnostics also enables automated assessment of morphological features, either to highlight areas of interest to the pathologist, such as the highest grade areas of tumours, or to identify subtle features of prognostic significance or predictive of response to therapy [132-134].

Immunohistochemistry for biomarker evaluation in research, either on series of tumour sections or on tissue microarrays, involves assessment of the intensity and distribution of protein expression, often on a very large number of tumours. This is very laborious and time-consuming work and is subject to considerable inter- and intra-observer variation. Image analysis systems have the capability of not only speeding up analysis and handling high volumes, but may also remove the element of subjectivity inherent in manual assessment [135]. There is also potential for simultaneous assessment of multiple biomarkers on the same tissue section. Pathologist input is, however, paramount for ensuring that the correct tissue area is assessed. Such technology is also potentially advantageous in clinical practice, as the introduction of any additional biomarker assessments adds work to an already stretched specialty [136].

For clinical trials, involving large numbers of centres, there is the opportunity to centrally review digital images of tumour samples, for quality assurance, and to maintain a central image library of cases for future analysis [137].

For teaching and education, digital pathology is also highly effective. ISUP now has an image database for urological pathology, which can be accessed online (www.isup. org) and provides an invaluable resource of renal tumour images for reference and promotes standardisation of diagnosis and tumour grading $[138,139]$. The capacity to annotate digital images enhances the educational value.

The wider availability of digital pathology for diagnostic use will, however, require significant investment in equipment, provision of efficient storage and retrieval facilities for the immense number of generated digital images, and for staff training. There is also a need to introduce guidelines and quality assurance checks to enable widespread use in clinical practice [140, 141]. Ultimately, it will require a culture change in the way pathology is practised in the future.

\section{Conclusion}

In recent years, there has been considerable progress in producing guidance for pathologists in the assessment of renal tumours, thus improving consistency in diagnosis, grading and staging. The development of additional immunohistochemical and molecular tests is needed to facilitate tumour typing, because of prognostic implications, and to enable more reliable identification of poorly differentiated metastatic tumours as being of renal origin. Any new tests need to be applicable to small biopsy samples, to overcome the heterogeneity of renal tumours. There is also a need to facilitate identification of tumour types that have genetic implications. This may mean automatic referral of certain categories of patient or tumours to specialist centres or establishing national referral centres for expert review and further tests. Digital pathology has a potential role in facilitating such referral practice.

Tumour grading has established prognostic significance, but it is still based upon subjective microscopic assessment and the extent of tumour sampling. It is also not applicable to all renal tumour types. The WHO/ISUP system has advantages over the former Fuhrman grading system, but finding ways of improving assignment of grade, enhancing its relevance, or introducing an alternative means of categorising tumours is also important for future patient management.

Author contributions AYW: project development, data collection, data analysis, manuscript writing and editing. DH: data analysis and editing

\section{Compliance with ethical standards}

Conflict of interest The authors declare that they have no relevant conflicts of interest. 
Research involving human participants and/or animals The following manuscript is a review of existing data. Therefore, this article does not contain any studies with human participants or animals performed by any of the authors.

Informed consent For this type of study (review) formal consent is not required.

Open Access This article is distributed under the terms of the Creative Commons Attribution 4.0 International License (http://creativeco mmons.org/licenses/by/4.0/), which permits unrestricted use, distribution, and reproduction in any medium, provided you give appropriate credit to the original author(s) and the source, provide a link to the Creative Commons license, and indicate if changes were made.

\section{References}

1. International Agency for Research on Cancer (2016) WHO classification of tumours of the urinary system and male genital organs (IARC WHO classification of tumours), 4th edn. WHO/ IARC Press, Lyon

2. Algaba F, Delahunt B, Berney DM, Camparo P, Compérat E, Griffiths D et al (2012) Handling and reporting of nephrectomy specimens for adult renal tumours: a survey by the European Network of Uropathology. J Clin Pathol 65:106-113

3. Delahunt B, Srigley JR, Montironi R, Egevad L (2014) Advances in renal neoplasia: recommendations from the 2012 International Society of Urological Pathology Consensus Conference. Urology 83:969-974

4. Delahunt B, Egevad L, Montironi R, Srigley JR (2013) International Society of Urological Pathology (ISUP) consensus conference on renal neoplasia: rationale and organization. Am J Surg Pathol 37:1463-1468

5. Delahunt B, Cheville JC, Martignoni G, Humphrey PA, MagiGalluzzi C, McKenney J et al (2013) The International Society of Urological Pathology (ISUP) grading system for renal cell carcinoma and other prognostic parameters. Am J Surg Pathol 37:1490-1504

6. Srigley JR, Delahunt B, Eble JN, Egevad L, Epstein JI, Grignon D et al (2013) The International Society of Urological Pathology (ISUP) Vancouver classification of renal neoplasia. Am J Surg Pathol 37:1469-1489

7. Tan PH, Cheng L, Rioux-Leclercq N, Merino MJ, Netto G, Reuter VE et al (2013) Renal tumors: diagnostic and prognostic biomarkers. Am J Surg Pathol 37:1518-1531

8. Trpkov K, Grignon DJ, Bonsib SM, Amin MB, Billis A, LopezBeltran A et al (2013) Handling and staging of renal cell carcinoma: the International Society of Urological Pathology Consensus (ISUP) conference recommendations. Am J Surg Pathol 37:1505-1517

9. Reuter VE, Argani P, Zhou M, Delahunt B, Members of the ISUP Immunohistochemistry in Diagnostic Urologic Pathology Group (2014) Best practices recommendations in the application of immunohistochemistry in the kidney tumors: report from the International Society of Urologic Pathology consensus conference. Am J Surg Pathol 38:e35-e49

10. Amin MB, Epstein JI, Ulbright TM, Humphrey PA, Egevad L, Montironi R et al (2014) Best practices recommendations in the application of immunohistochemistry in urologic pathology: report from the International Society of Urological Pathology consensus conference. Am J Surg Pathol 38:1017-1022
11. Delahunt B, Srigley J, Amin M, Billis A, Camparo P, Evans A et al (2017) Invasive carcinoma of renal tubular origin, histopathology reporting guide, 1st edn. International Collaboration on Cancer Reporting, Sydney

12. Delahunt B, Srigley J, Amin M, Billis A, Camparo P, Evans A et al (2017) Renal biopsy for tumour, histopathology reporting guide, 1st edn. International Collaboration on Cancer Reporting, Sydney

13. Warren AY, Griffiths D, Fleming S (2017) Dataset for histopathological reporting of adult renal parenchyma neoplasms, 3rd edn. The Royal College of Pathologists, London

14. Moch H, Gasser T, Amin MB, Torhorst J, Sauter G, Mihatsch MJ (2000) Prognostic utility of the recently recommended histologic classification and revised TNM staging system of renal cell carcinoma: a Swiss experience with 588 tumors. Cancer 89:604-614

15. Ljungberg B, Alamdari FI, Stenling R, Roos G (1999) Prognostic significance of the Heidelberg classification of renal cell carcinoma. Eur Urol 36:565-569

16. Murphy WM, Grignon DJ, Perlman EJ (2004) Tumours of the kidney, bladder and related urinary structures, vol 4. AFIP atlas of tumour pathology. American Registry of Pathology, Washington

17. Kim H, Cho NH, Kim DS, Kwon YM, Kim EK, Rha SH et al (2004) Renal cell carcinoma in South Korea: a multicenter study. Hum Pathol 35:1556-1563

18. Srigley JR, Delahunt B (2009) Uncommon and recently described renal carcinomas. Mod Pathol 22:S2-S23

19. Novara G, Ficarra V, Antonelli A, Artibani W, Bertini R, Carini $M$ et al (2010) Validation of the 2009 TNM version in a large multi-institutional cohort of patients treated for renal cell carcinoma: are further improvements needed? Eur Urol 58:588-595

20. Leibovich BC, Lohse CM, Crispen PL, Boorjian SA, Thompson $\mathrm{RH}$, Blute ML et al (2010) Histological subtype is an independent predictor of outcome for patients with renal cell carcinoma. J Urol 183:1309-1315

21. O'Brien MF, Russo P, Motzer RJ (2008) Sunitinib therapy in renal cell carcinoma. BJU Int 101:1339-1342

22. Cheville JC, Lohse CM, Zincke H, Weaver AL, Blute ML (2003) Comparisons of outcome and prognostic features among histologic subtypes of renal cell carcinoma. Am J Surg Pathol 27:612-624

23. Steffens S, Roos FC, Janssen M, Becker F, Steinestel J, Abbas $M$ et al (2014) Clinical behaviour of chromophobe renal cell carcinoma is less aggressive than that of clear cell renal cell carcinoma, independent of Fuhrman grade or tumor size. Virchows Arch 465:439-444

24. Amin MB, Amin MB, Tamboli P, Javidan J, Stricker H, de Venturina MP et al (2002) Prognostic impact of histologic subtypes of adult renal epithelial neoplasms: an experience of 405 cases. Am J Surg Pathol 26:281-291

25. Nickerson ML, Jaeger E, Shi Y, Durocher JA, Mahurkart S, Zaridze D et al (2008) Improved identification of von HippelLindau gene alterations in clear cell renal tumours. Clin Cancer Res 14:4726-4734

26. Maher ER (2018) Hereditary renal cell carcinoma syndromes: diagnosis, surveillance and management. World J Urol. https:// doi.org/10.1007/s00345-018-2288-5. [Epub ahead of print]

27. Taneja K, Arora S, Rogers CG, Gupta NS, Williamson SR (2018) Pathologic staging of renal cell carcinoma: a review of 300 consecutive cases with emphasis on retrograde venous invasion. Histopathology https://doi.org/10.1111/his.13672. [Epub ahead of print]

28. Bhatt JR, Jewett MA, Richard PO, Kawaguchi S, Timilshina N, Evans A et al (2016) Multilocular cystic renal cell carcinoma: 
pathological $\mathrm{T}$ staging makes no difference to favourable outcomes and should be reclassified. J Urol 196(5):1350-1355

29. Delahunt B, Eble JN (1997) Papillary renal cell carcinoma: a clinicopathologic and immunohistochemical study of 105 tumors. Mod Pathol 10:537-544

30. Adeniran AJ, Shuch B, Humphrey PA (2015) Hereditary renal cell carcinoma syndromes. Clinical, pathologic and genetic features. Am J Surg Pathol 39(12):e1-e18

31. Delahunt B, Eble JN, McCredie MR, Bethwaite PB, Stewart JH, Bilous AM (2001) Morphologic typing of papillary renal cell carcinoma: comparison of growth kinetics and patient survival in 66 cases. Hum Pathol 32:590-595

32. Cancer Genome Atlas Research Network, Linehan WM, Spellman PT, Ricketts CJ, Creighton CJ et al (2016) Comprehensive molecular characterisation of papillary renal cell carcinomas. N Engl J Med 374(2):135-145

33. Flippot R, Comperat E, Tannir NM, Maloaf GG (2018) Papillary renal cell carcinoma: a family portrait. Eur Urol 73:79-80

34. Saleeb RM, Brimo F, Farag M, Rompré-Brodeur A, Rotondo F, Beharry V (2017) Toward biological subtyping of papillary renal cell carcinoma with clinical implications through histologic, immunohistochemical and molecular analysis. Am J Surg Pathol 41:1618-1629

35. Ren Q, Wang L, Al-Ahmadie HA, Fine SW, Gopalan A, Sirintrapun SJ et al (2018) Distinct genomic copy number alterations distinguish mucinous tubular and spindle cell carcinoma of the kidney from papillary renal cell carcinoma with overlapping histologic features. Am J Surg Pathol 42(6):767-777

36. Shuch B, Amin A, Armstrong AJ, Eble JN, Ficarra V, LopezBeltran A et al (2015) Understanding pathologic variants of renal cell carcinoma: distilling therapeutic opportunities from biologic complexity. Eur Urol 67:85-97

37. Tan MH, Wong CF, Tan HL, Yang XJ, Ditley J, Matsuda D et al (2010) Genomic expression and single nucleotide polymorphism profiling discriminates chromophobe renal cell carcinoma and oncocytoma. BMC Cancer 10:196

38. Pavlovich CP, Walther MM, Eyler RA, Hewitt SM, Zbar B, Linehan WM et al (2002) Renal tumors in the Birt-Hogg-Dubé syndrome. Am J Surg Pathol 26:1542-1552

39. Ohe C, Smith SC, Sirohi D, Divatia M, de Peralta-Venturina M, Paner GP et al (2018) Reappraisal of morphologic differences between renal medullary carcinoma, collecting duct carcinoma and fumarate hydratase-deficient renal cell carcinoma. Am J Surg Pathol 42:279-292

40. Argani P (2015) MiT family translocation renal cell carcinomas. Semin Diagn Pathol 32:103-113

41. Cutruzzula P, Cahn D, Kivlin D, Tong C, Edwards D, Amster M (2016) A review of translocation $t(6 ; 11)$ renal cell carcinoma tumours in the adult patient. Curr Urol 10:69-71

42. Zhou H, Zheng S, Truong LD, Ro JY, Ayala AG, Shen SS (2014) Clear cell papillary renal cell carcinoma is the fourth most common histological type of renal cell carcinomas in 290 consecutive nephrectomies for renal cell carcinoma. Hum Pathol 45:59-64

43. Przybycin CG, Harper HL, Reynolds JP, Magi-Galluzzi C, Nguyen JK, Wu A et al (2018) Acquired cystic disease-associated renal cell carcinoma (ACD-RCC): a multiinstitutional study of 40 cases with clinical follow-up. Am J Surg Pathol 42:1156-1165. https://doi.org/10.1097/pas.0000000000001091 [Epub ahead of print]

44. Amin MB, MacLennan GT, Gupta R, Grignon D, Paraf F, Vieillefond A et al (2009) Tubulocystic carcinoma of the kidney: clinicopathologic analysis of 31 cases of a distinctive rare subtype of renal cell carcinoma. Am J Surg Pathol 33:384-392

45. Tran T, Jones CL, Williamson SR, Eble JN, Grignon DJ, Zhang S et al (2016) Tubulocystic renal cell carcinoma is an entity that is immunohistochemically and genetically distinct from papillary renal cell carcinoma. Histopathology 68:850-857

46. Zhang P, Yang X, Yu L, Wu Y, Wang C (2017) Tubulocystic renal cell carcinoma of the kidney: a clinical, pathological, immunohistochemical, and fluorescence in situ hybridization study. Int J Clin Exp Pathol 10(3):3327-3334

47. Lawrie $\mathrm{CH}$, Armesto M, Fernandez-Mercado M, Arestin M, Manterola L, Goicoechea I (2018) Noncoding RNA expression and targeted next-generation sequencing distinguish tubulocystic renal cell carcinoma (TC-RCC) and other renal neoplasms. J Mol Diagn 20(1):34-45

48. Menko FH, Maher ER (2016) Diagnostic and management of hereditary renal cell cancer. Recent Results Cancer Res 205:85-104

49. Gill AJ (2018) Succinate dehydrogenase (SDH)-deficient neoplasia. Histopathology 72:106-116

50. Williamson SR, Eble JN, Amin MB, Gupta NS, Smith SC, Sholl LM et al (2015) Succinate dehydrogenase-deficient renal cell carcinoma: detailed characterisation of 11 tumors defining a unique subtype of renal cell carcinoma. Mod Pathol 28:80-94

51. Chen Y-B, Brannon R, Toubaji A, Dudas ME, Won HH, AlAhmadie HA et al (2014) Hereditary leiomyomatosis and renal cell carcinoma syndrome-associated renal cancer: recognition of the syndrome by pathologic features and the utility of detecting aberrant succination by immunohistochemistry. Am J Surg Pathol 38(5):627-637

52. Merino MJ, Torres-Cabala C, Pinto P, Lineman WM (2007) The morphological spectrum of kidney tumours in hereditary leiomyomatosis and renal cell carcinoma (HLRCC) syndrome. Am J Surg Pathol 31:1578-1585

53. Grubb RL 3rd, Franks ME, Toro J, Middleton L, Choyke L, Fowler S et al (2007) Hereditary leiomyomatosis and renal cell cancer: a syndrome associated with an aggressive form of inherited renal cancer. J Urol 177:2074-2079

54. Trpkov K, Hes O, Agaimy A, Bonert M, Martinek P, MagiGalluzzi C et al (2016) Fumarate hydratase-deficient renal cell carcinoma is strongly correlated with fumarate hydratase mutation and hereditary leiomyomatosis and renal cell carcinoma syndrome. Am J Surg Pathol 40(7):865-875

55. Smith SC, Trpkov K, Chen Y-B, Mehra R, Sirohi D, Ohe C et al (2016) Tubulocystic carcinoma of the kidney with poorly differentiated foci: a frequent morphological pattern of fumarate hydratase-deficient renal cell carcinoma. Am J Surg Pathol 40(11):1457-1472

56. Guo J, Tretiakova MS, Troxwell ML, Osunkoya AO, Fadare O, Sangoi AR et al (2014) Tuberous sclerosis-associated renal cell carcinoma. A clinicopathological study of 57 separate carcinomas in 18 patients. Am J Surg Pathol 38(11):1457-1467

57. Yang P, Cornejo KM, Sadow PM, Cheng L, Wang M, Xiao Y et al (2014) Renal cell carcinoma in tuberous sclerosis complex. Am J Surg Pathol 38:895-909

58. Trpkov K, Hes O, Bonert M, Lopez JI, Bonsib SM, Nesi G et al (2016) Eosinophilic solid and cystic renal cell carcinoma. Clinicopathological study of 16 unique sporadic neoplasms occurring in women. Am J Surg Pathol 40(1):60-71

59. Trpkov K, Abou-Ouf H, Hes O, Lopez JI, Nesi G, Comperat E, Sibony M et al (2017) Eosinophilic solid and cystic renal cell carcinoma (ESC RCC). Further morphologic and molecular characterisation of ESC RCC as a distinct entity. Am J Surg Pathol 41(10): 1299-1308

60. Li Y, Reuter VE, Matoso A, Netto GJ, Epstein JI, Argani P (2018) Re-evaluation of 33 'unclassified' eosinophilic renal cell carcinomas in young patients. Histopathology 72:588-600

61. Palsgrove DN, Li Y, Pratilas C, Lin MT, Pallavajjalla A, Gocke $\mathrm{C}$ et al (2018) Eosinophilic solid and cystic (ESC) renal cell carcinomas harbour TSC mutations: molecular analysis supports 
an expanding clinicopathological spectrum. Am J Surg Pathol 42:1166-1181. https://doi.org/10.1097/pas.0000000000001111 [Epub ahead of print]

62. Parilla M, Kadri S, Patil SA, Ritterhouse L, Segal J, Henriksen $\mathrm{KJ}$ et al (2018) Are sporadic eosinophilic solid and cystic renal cell carcinomas characterised by somatic tuberous sclerosis gene mutations? Am J Surg Pathol 42(7):911-917

63. Perrino CM, Grignon DJ, Williamson SR, Idrees MT, Eble JN, Cheng L (2018) Morphological spectrum of renal cell carcinoma, unclassified: an analysis of 136 cases. Histopathology 72(2):305-319

64. Kryvenko ON, Jorda M, Argani P, Epstein J (2014) Diagnostic approach to eosinophilic renal neoplasms. Arch Pathol Lab Med 138(11):1531-1541

65. Williamson SR, Gadde R, Trpkov K, Hirsch MS, Srigley JR, Reuter VE et al (2017) Diagnostic criteria for oncocytic renal neoplasms: a survey of urologic pathologists. Hum Pathol 63:149-156

66. Fuhrman SA, Lasky LC, Limas C (1982) Prognostic significance of morphologic parameters in renal cell carcinoma. Am J Surg Pathol 6:655-663

67. Sika-Paotonu D, Bethwaite PB, McCredie MR, William Jordan T, Delahunt B (2006) Nucleolar grade but not Fuhrman grade is applicable to papillary renal cell carcinoma. Am J Surg Pathol 30:1091-1096

68. Delahunt B (2009) Advances and controversies in grading and staging of renal cell carcinoma. Mod Pathol 22:S24-S36

69. Delahunt B, Sika-Paotonu D, Bethwaite PB, McCredie MR, Martignoni G, Eble JN et al (2007) Fuhrman grading is not appropriate for chromophobe renal cell carcinoma. Am J Surg Pathol 31:957-960

70. Delahunt B, Sika-Paotonu D, Bethwaite PB, William Jordan T, Magi-Galluzzi C, Zhou M et al (2011) Grading of clear cell renal cell carcinoma should be based on nucleolar prominence. Am J Surg Pathol 35:1134-1139

71. Finley DS, Shuch B, Said JW, Galliano G, Jeffries RA, Afifi AA et al (2011) The chromophobe tumor grading system is the preferred grading scheme for chromophobe renal cell carcinoma. J Urol 186:2168-2174

72. Paner GP, Amin MB, Alvarado-Cabrero I, Young AN, Stricker $\mathrm{HJ}$, Moch $\mathrm{H}$ et al (2010) A novel tumor grading scheme for chromophobe renal cell carcinoma: prognostic utility and comparison with Fuhrman nuclear grade. Am J Surg Pathol 34:1233-1240

73. Delahunt B, McKenney JK, Lohse CM, Leibovich BC, Thompson RH, Boorjian SA et al (2013) A novel grading system for clear cell renal cell carcinoma incorporating tumor necrosis. Am J Surg Pathol 37:311-322

74. Khor LY, Dhakal HP, Jia X, Reynolds JP, McKenney JK, Rini BI et al (2016) Tumor necrosis adds prognostically significant information to grade in clear cell renal cell carcinoma: a study of 842 consecutive cases from a single institution. Am J Surg Pathol 40:1224-1231

75. Verine J, Colin D, Nheb M, Prapotnich D, Ploussard G, Cathelineau X et al (2018) Architectural patterns are a relevant morphologic grading system for clear cell renal cell carcinoma prognosis assessment. Am J Surg Pathol 42(4):423-441

76. Leibovich BC, Blute ML, Cheville JC, Lohse CM, Frank I, Kwon ED et al (2003) Prediction of progression after radical nephrectomy for patients with clear cell renal cell carcinoma: a stratification tool for prospective clinical trials. Cancer 97:1663-1671

77. Amtrup F, Hansen JB, Thybo E (1974) Prognosis in renal carcinoma evaluated from histological criteria. Scand J Urol Nephrol 8:198-202

78. Thompson RH, Cheville JC, Lohse CM, Webster WS, Zincke H, Kwon ED et al (2005) Reclassification of patients with pT3 and
pT4 renal cell carcinoma improves prognostic accuracy. Cancer 104:53-60

79. Sengupta S, Lohse CM, Leibovich BC, Frank I, Thompson RH, Webster WS et al (2005) Histologic coagulative tumor necrosis as a prognostic indicator of renal cell carcinoma aggressiveness. Cancer 104:511-520

80. Peckova K, Martinek P, Pivovarcikova K, Vanecek T, Alaghehbandan R, Prochazkova K et al (2017) Cystic and necrotic papillary renal cell carcinoma: prognosis, morphology, immunohistochemical and molecular-genetic profile of 10 cases. Ann Diagn Pathol 26:23-30

81. Peckova K, Vanecek T, Martinek P, Spangnolo D, Kurdoda N, Brunelli $\mathrm{M}$ et al (2014) Aggressive and nonaggressive translocation $t(6 ; 11)$ renal cell carcinoma: comparative study of 6 cases and review of the literature. Ann Diagn Pathol 18:351-357

82. Collins J, Epstein JI (2017) Prognostic significance of extensive necrosis in renal cell carcinoma. Hum Pathol 66:108-114

83. Park JY, Lee JL, Baek S, Eo SH, Go H, Ro JY et al (2014) Sarcomatoid features, necrosis, and grade are prognostic factors in metastatic clear cell renal cell carcinoma with vascular endothelial growth factor-targeted therapy. Hum Pathol 45(7):1437-1444

84. Ficarra V, Novara G, Iafrate M, Cappellaro L, Bratti E, Zattoni $F$ et al (2007) Proposal for reclassification of the TNM staging system in patients with locally advanced (pT3-4) renal cell carcinoma according to the cancer-related outcome. Eur Urol $51: 722-729$

85. Klatte T, Said JW, de Martino M, Larochelle J, Shuch B, Rao $J Y$ et al (2009) Presence of tumor necrosis is not a significant predictor of survival in clear cell renal cell carcinoma: higher prognostic accuracy of extent based rather than presence/absence classification. J Urol 181:1558-1564

86. Renshaw AA, Cheville JC (2015) Quantitative tumour necrosis is an independent predictor of overall survival in clear cell renal cell carcinoma. Pathology 47:34-37

87. Cheville JC, Lohse CM, Zincke H, Weaver AL, Leibovich BC, Frank I et al (2004) Sarcomatoid renal cell carcinoma: an examination of underlying histologic subtype and an analysis of associations with patient outcome. Am J Surg Pathol 28:435-441

88. Cangiano T, Liao J, Naitoh J, Dorey F, Figlin R, Belldegrun A (1999) Sarcomatoid renal cell carcinoma: biologic behavior, prognosis, and response to combined surgical resection and immunotherapy. J Clin Oncol 17:523-528

89. Delahunt B (1999) Sarcomatoid renal carcinoma: the final common dedifferentiation pathway of renal epithelial malignancies. Pathology 31:185-190

90. de Peralta-Venturina M, Moch H, Amin M, Tamboli P, Hailemariam S, Mihatsch M et al (2001) Sarcomatoid differentiation in renal cell carcinoma: a study of 101 cases. Am J Surg Pathol 25:275-284

91. Lebacle C, Pooli A, Bessede T, Irani J, Pantuck AJ, Drakaki A (2018) Epidemiology, biology and treatment of sarcomatoid RCC: current state of the art. World J Urol. https://doi. org/10.1007/s00345-018-2355

92. Zhang BY, Thompson RH, Lohse CM, Leibovich BC, Boorjian SA, Cheville JC et al (2015) A novel prognostic model for patients with sarcomatoid renal cell carcinoma. BJU Int 115:405-411

93. Adibi M, Thomas AZ, Borregales LD, Merrill MM, Slack RS, Chen HC et al (2015) Percentage of sarcomatoid component as a prognostic indicator for survival in renal cell carcinoma with sarcomatoid dedifferentiation. Urol Oncol 33:e17-e23

94. Kuroiwa K, Kinoshita Y, Shiratsuchi H, Oshiro Y, Tamiya S, Oda $Y$ et al (2002) Renal cell carcinoma with rhabdoid features: an aggressive neoplasm. Histopathology 41:538-548 
95. Gökden N, Nappi O, Swanson PE, Pfeifer JD, Vollmer RT, Wick MR et al (2000) Renal cell carcinoma with rhabdoid features. Am J Surg Pathol 24:1329-1338

96. Przybycin CG, McKenney JK, Reynolds JP, Campbell S, Zhou M, Karafa MT et al (2014) Rhabdoid differentiation is associated with aggressive behaviour in renal cell carcinoma: a clinicopathological analysis of 76 cases with clinical follow-up. Am J Surg Pathol 38(9):1260-1265

97. Leroy X, Zini L, Buob D, Ballereau C, Villers A, Aubert S (2007) Renal cell carcinoma with rhabdoid features: an aggressive neoplasm with overexpression of p53. Arch Pathol Lab Med 131:102-106

98. Agaimy A, Cheng L, Egevad L, Feyerabend B, Hes O, Keck B et al (2017) Rhabdoid and undifferentiated phenotype in renal cell carcinoma: analysis of 32 cases indicating a distinctive common pathway of dedifferentiation frequently associated with SWI/SNF complex deficiency. Am J Surg Pathol 41(2):253-262

99. Zhang BY, Cheville JC, Thompson RH, Lohse CM, Boojian SA, Leibovich BC et al (2015) Impact of rhabdoid differentiation on prognosis for patients with grade four renal cell carcinoma. Eur Urol 68:5-7

100. Bonsib SM (2008) Macroscopic assessment, dissection protocols and histologic sampling strategy for renal cell carcinomas. Diagn Histopathol 14:151-156

101. Sobin LH, Gospodarowicz MK, Wittekind C (2009) TNM classification of malignant tumours (UICC International Union Against Cancer), 7th edn. Wiley-Blackwell, Oxford

102. Edge S, Byrd DR, Compton CC, Fritz AG, Greene FL, Trotti A (2011) AJCC cancer staging manual, 7th edn. Springer, New York

103. Amin MB, Edge SB, Greene FL, Byrd DR, Brookland RK, Washington MK et al (2016) AJCC cancer staging manual, 8th edn. Springer, New York

104. Brierley JD, Gospodarowicz MK, Wittekind C (2017) TNM classification of malignant tumours, 8th edn. Wiley-Blackwell, Hoboken

105. Delahunt B, Egevad L, Samaratunga H, Varma M, Verrill C, Cheville J et al (2017) UICC drops the ball in the 8th edition TNM staging of urological cancers. Histopathology 71:5-11

106. Paner GP, Stadler WM, Hansel DE, Montironi R, Lin DW, Amin MB (2018) Updates in the eighth edition of the tumor-nodemetastasis staging classification for urologic cancers. Eur Urol 73(4):560-569

107. Delahunt B, Kittelson JM, McCredie MR, Reeve AE, Stewart JH, Bilous AM (2002) Prognostic importance of tumor size for localized conventional (clear cell) renal cell carcinoma: assessment of TNM T1 and T2 tumor categories and comparison with other prognostic parameters. Cancer 94:658-664

108. Bonsib SM (2005) T2 clear cell renal cell carcinoma is a rare entity: a study of 120 clear cell renal cell carcinomas. J Urol 174:1199-1202

109. Thomas DH, Verghese A, Kynaston HG, Griffiths DF (2003) Analysis of the prognostic implications of different tumour margin types in renal cell carcinoma. Histopathology 43:374-380

110. Bonsib SM, Gibson D, Mhoon M, Greene GF (2000) Renal sinus involvement in renal cell carcinomas. Am J Surg Pathol 24:451-458

111. Bonsib SM (2006) Renal lymphatics, and lymphatic involvement in sinus vein invasive (pT3b) clear cell renal cell carcinoma: a study of 40 cases. Mod Pathol 19:746-753

112. Bonsib SM (2007) Renal veins and venous extension in clear cell renal cell carcinoma. Mod Pathol 20:44-53

113. Thompson RH, Leibovich BC, Cheville JC, Webster WS, Lohse $\mathrm{CM}, \mathrm{Kwon} \mathrm{ED}$ et al (2005) Is renal sinus fat invasion the same as perinephric fat invasion for $\mathrm{pT} 3 \mathrm{a}$ renal cell carcinoma? J Urol 174:1218-1221

114. Bailey GC, Boorjian SA, Ziegelmann MJ, Westerman ME, Lohse CM, Leibovich BC et al (2017) Urinary collecting system invasion is associated with poor survival in patients with clear-cell renal cell carcinoma. BJU Int 119:585-590

115. Chen L, Ma X, Li H, Li X, Gao Y, Zhang Y et al (2016) Invasion of the urinary collecting system is an independent prognostic factor in pT3 renal cell carcinoma. Urol Oncol 34:e11-e16

116. Verhoest G, Avakian R, Bensalah K, Thuret R, Ficarra V, Artibani W et al (2009) Urinary collecting system invasion is an independent prognostic factor of organ confined renal cell carcinoma. J Urol 182:854-859

117. Chen L, Li H, Gu L, Ma X, Li X, Zhang F et al (2016) Prognostic role of urinary collecting system invasion in renal cell carcinoma: a systematic review and meta-analysis. Sci Rep 6:21325

118. O'Malley RL, Godoy G, Kanofsky JA, Taneja SS (2009) The necessity of adrenalectomy at the time of radical nephrectomy: a systematic review. J Urol 181:2009-2017

119. Saitoh H, Nakayama M, Nakamura K, Satoh T (1982) Distant metastasis of renal adenocarcinoma in nephrectomized cases. J Urol 127:1092-1095

120. Madbouly K, Al-Qahtani SM, Ghazwani Y, Al-Shaibani S, Mansi MK (2007) Microvascular tumor invasion: prognostic significance in low-stage renal cell carcinoma. Urology 69:670-674

121. Lang H, Lindner V, Letourneux H, Martin M, Saussine C, Jacqmin D (2004) Prognostic value of microscopic venous invasion in renal cell carcinoma: long-term follow-up. Eur Urol 46:331-335

122. Griffiths DF, Verghese A, Golash A, Kynaston HG, Matthews PN, Hart AJ et al (2002) Contribution of grade, vascular invasion and age to outcome in clinically localized renal cell carcinoma. BJU Int 90:26-31

123. Kroeger N, Rampersaud EN, Patard JJ, Klatte T, Birkhäuser FD, Shariat SF et al (2012) Prognostic value of microvascular invasion in predicting the cancer specific survival and risk of metastatic disease in renal cell carcinoma: a multicenter investigation. J Urol 187:418-423

124. Karellas M, Jang T, Kagiwada M, Kinnaman M, Jarnagin W, Russo P (2009) Advanced-stage renal cell carcinoma treated by radical nephrectomy and adjacent organ or structure resection. BJU Int 103:160-164

125. Liu N, Wren J, Vertosick E, Lee J, Power N, Benfante N et al (2016) The prognostic impact of a positive vascular margin on pT3 clear cell renal cell carcinoma. J Urol 195:264-269

126. Antic T, Taxy JB (2015) Partial nephrectomy for renal tumors: lack of correlation between margin status and local recurrence. Am J Clin Pathol 143:645-651

127. Patel H, Johnson M, Pierorazio P, Sozio S, Sharma R, Iyoha E et al (2016) Diagnostic accuracy and risks of biopsy in the diagnosis of a renal mass suspicious for localized renal cell carcinoma: systematic review of the literature. J Urol 195:1340-1347

128. Jeon H, Seo S, Jeong B, Jeon S, Lee H, Choi H et al (2016) Percutaneous kidney biopsy for a small renal mass: a critical appraisal of results. J Urol 195:568-573

129. Delahunt B, Samaratunga H, Martignoni G, Srigley J, Evans A, Brunelli M (2014) Percutaneous renal tumour biopsy. Histopathology 65:295-308

130. Evans A, Delahunt B, Srigley J (2015) Issues and challenges associated with classifying neoplasms in percutaneous needle biopsies of incidentally found small renal masses. Semin Diagn Pathol 32:184-195

131. Williams BJ, Bottoms D, Treanor D (2017) Future-proofing pathology: the case for clinical adoption of digital pathology. J Clin Pathol 70:1010-1081 
132. Mezheyeuski A, Hrynchyk I, Karlberg M, Portyanko A, Egevad L, Ragnhammar P et al (2016) Image analysis-derived metrics of histomorphological complexity predicts prognosis and treatment response in stage II-III colon cancer. Sci Rep 6:36149. https:// doi.org/10.1038/srep36149

133. Jansen I, Lucas M, Savci-Heijink CD, Meijer SL, Marquering HA, de Bruin DM et al (2018) Histopathology: ditch the slides, because digital and 3D are on show. World J Urol 36:549-555

134. Raza Ali H, Dariush A, Provenzano E, Bardwell H, Abraham JE, Iddawela $\mathrm{M}$ et al (2016) Computational pathology of pretreatment biopsies identifies lymphocyte density as a predictor of response to neoadjuvant chemotherapy in breast cancer. Breast Cancer Res 18:21

135. Hamilton PW, Bankhead P, Wang Y, Hutchinson R, Kieran D, McArt DG et al (2014) Automated analysis for molecular profiling in lung cancer. Methods 70:59-73

136. Koelzer VH, Gisler A, Hanhart JC, Griss J, Wagner SN, Willi $\mathrm{N}$ et al (2018) Digital image analysis improves precision of programmed death ligand 1 (PD-L1) scoring in cutaneous melanoma. Histopathology https://doi.org/10.1111/his.13528 [Epub ahead of print]

137. Mroz P, Parwani A, Kulesza P (2013) Central pathology review for phase III clinical trials. The enabling effect of virtual microscopy. Arch Pathol Lab Med 137:492-495

138. Egevad L, Cheville J, Evans AJ, Hörnblad J, Kench JG, Kristiansen $\mathrm{G}$ et al (2017) Pathology imagebase - a reference image database for standardisation of pathology. Histopathology 71(5):677-685

139. Egevad L, Delahunt B, Berney DM, Bostwick DG, Cheville J, Comperat E et al (2018) Utility of pathology imagebase for standardisation of prostate cancer grading. Histopathology 7:818. https://doi.org/10.1111/his.13471 [Epub ahead of print]

140. Griffin J, Treanor D (2017) Digital pathology in clinical use: where are we now and what is holding us back? Histopathology 70:134-145

141. Cross S, Furness P, Igali L, Snead D, Treanor D (2018) Best practice recommendations for implementing digital pathology. The Royal College of Pathologists, London 